CLASSIFICATION OF THE FOSSORIAL, PREDACEOUS AND PARASITIC WASPS, OR THE SUPERFAMILY VESPOIDEA.

By William H. ashmead, M. A., D. SC., ASSistant CURAToR, U. S. NATIONAL MUSEUM.

(Paper No. 16.-Continued from Vol. XXXV., p. 205.)

Family XLII.-Mutillidæ.

I 830. Mutillidæ, Family (partim), Leach ; Edinb. Ency., IX., p. I 45.

I 855. Mutillidæ, Family (partim), Smith ; Cat. Hym. Brit. Mus., III., p. I.

I 899. Mutillidæ, Family XLII., Ashmead ; Journ. N. Y. Ent. Soc., VII., p. 49 .

I 899. Mutillidæ, Family (partim), Fox; Trans. Aın. Ent. Soc., XXV., p. 220.

1899. Mutillidæ, Famille (partim), André ; Spec. Hym. d'Eur. Tom. VIII., pp. I -77 .

I 903. Mutillidæ, Famille (partim), André ; Wytsman's Gen. Ins., Fam. Mutillidæ.

William E. Leach, and not Frederick Smith, as Ernest André has it, was the first to establish the family Mutillidce; but none of these gentlemen correctly defined it, and all have included genera which do not belong to it. Some of the genera belong to the Bethylida, one belongs to the Thynnidce, one to the Cosilida, and others to the Myrmosidce.

The family, as here restricted, contains only wingless females, with the thorax always undivided, or without trace of the pronotal or mesonotal sutures, while the males are easily distinguished from those in other families by having the abdomen terminating in two slender, straight spines, which usually project from between the two plates of the pygidium - the epipygium and the hypopygium. All other writers on these wasps, namely, Klug, Lepeletier, Leach, Haliday, Radoszkowski, Sichel, Smith, Saussure, Blake, Cresson, Fox, Peringuey and André, have, in my opinion, included in the family genera or groups which do not belong to it, but which fall naturally into other families, as I have clearly shown in my characterization of the families. All its members are genuine parasites, and live in the nests of various bees and wasps. The family may be separated into two closely-allied subfamilies, as follows : 
Table of Subfamilies.

Abdomen with the first segment broadly sessile with the second, without a distinct constriction or furrow between, and never much narrowed or petioliform, although sometimes subnodose in some

males................... Subfamily I., Mutillinæ. Abdomen with the first segment petiolate or petioliform, never broadly sessile with the second, but much narrowed at apex, and usually with a constriction or furrow between it and the second................... Subfamily II., Ephutinæ.

Subfamily I.-Mutillinæ.

This group has apparently reached its highest development in Europe, Africa and Asia, the typical forms found in America being less numerous; the others show a closer affinity with the next subfamily or the Ephutince, tribe Sphaerophthalmini.

Two minor groups or tribes may be recognized by the following characters :

Eyes small, rounded, hemispherical or ellipsoidal, prominently convex, smooth and highly polished, not facetted, or with the facets vaguely defined, except in ot Tricholabiodes, Pseudophotopsis and Alloneurion, which have large oval eyes, more or less facetted, that extend to the base of the mandibles.............. Tribe I., Photopsidini. Eyes larger, not rounded or hemispherical, ovate, obovate or ellipsoidal, always distinctly facetted, and in the of sometimes emarginate within .....................

TRIBE I.-Photopsidini.

The majority of the males in this group more closely resemble those in the family Myrmosidæ, tribe Chyphotini, than any of the others, and this resemblance has influenced me in placing the tribe at the head of the family Mutillidce, although in cephalic characters, and particularly in the rounded eyes, they are evidently allied to the tribe Sphaerophthalmini, some of the females having been described originally in the genus Sphaerophthalma, Blake.

Males.

Table of Genera.

Females

I. Eyes large, oval, not hemispherical, occupying most of the sides of the head and extending to base of mandibles, usually with a feeble sinus in front and behind, delicately facetted ........ 
Eyes not large, hemispherical or rounded.

2. Postscutellum armed on each side with a small erect tooth or spine; mesonotum with complete furrows $\ldots \ldots \ldots \ldots \ldots \ldots \ldots \ldots$. Postscutellum normal, unarmed.

Front wings with three cubital cells, the third sometimes incomplete, the stigma very small and indistinct; only one recurrent nervure; mandibles strongly excised beneath, 3 -dentate at apex; middle and hind tibiæ armed with spines. (Africa ) ............. Tricholabiodes, Radoszkowski. (Type Mutilla pedunculata, Klug.)

3. Front wings with two cubital cells and only one recurrent nervure ; both mandibles excised beneath, with a process or projection before the incision; ocelli large. (Africa, Asia.) ...................... Pseudophotopsis, André.

(Type Agama Kamarovi, Radosz ) Front wings with three cubital cells and with two recurrent nervures, the third cubital cell again divided by a longitudinal vein issuing from the middle of the second transverse cubitus. (Asia $) \ldots \ldots \ldots \ldots \ldots \ldots \ldots$ Alloneurion, Ashmead.

(Type Mutilla Kokpetica, Radosz.)

4. Mesosternum anteriorly normal, unarmed............

Mesosternum anteriorly abnormal, armed with two (or more) teeth.

Head quadrate, the temples full; mandibles at apex 4-dentate; mesosternum laterally at the middle armed with a tooth; first joint of the flagellum as long or nearly as the second. (North America.) . . . . . . . . . Tetraphotopsis, Ashm., gen. nov.

(Type T. Hubbardi, Ashm.)

Head not quadrate, the temples not full; mandibles at apex 3-dentate; mesosternum laterally unarmed; first joint of the flagellum shorter than the second. (North America.)................ Odontophotopsis, Viereck.

(Type O. exogyrus, Viereck.)

5. Marginal cell at apex pointed or rounded, but never broadly

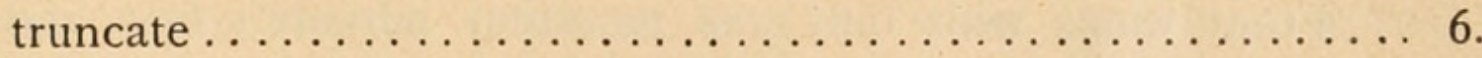

Marginal cell at apex broadly, squarely truncate $\ldots \ldots \ldots \ldots \ldots$ I 5 .

6. Mandibles beneath excised, or with a sinus and usually with a tooth, or process, before the incision, or at least the left mandible excised beneath 
Mandibles beneath simple, not excised..............

7. Mandibles acuminate, or with a tooth within before apex, never

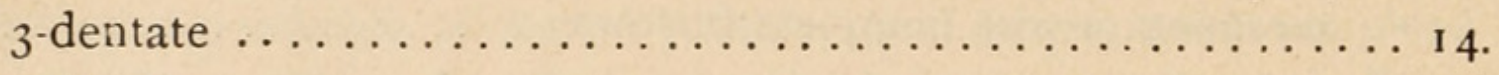

Mandibles stout and strong throughout, at apex $\hat{3}$-dentate.

Front wings with only one recurrent nervure $\ldots \ldots \ldots \ldots \ldots$.

Front wings with two recurrent nervures $\ldots \ldots \ldots \ldots \ldots \ldots$ I 3 .

8. Ocelli large; submedian cell a little longer than the median; first and second joints of the flagellum cylindrical, more than twice longer than thick, and about equal in length. (North America.) ............... Neophotopsis, Ashm., gen. nov.

(Type Photopsis pluto, Fox.)

Ocelli small ; submedian cell not longer than the median; first joint of the flagellum a little longer than thick and shorter than the second. (North America.)......... Bruesia, Ashm., gen. nov.

(Type Mutilla harmonia, Fox.)

9. Front wings with three cubital cells, or the third partially formed.. I 2. Front wings with two cubital cells, the third entirely absent.

Mesonotum with distinct parapsidal furrows ............

Mesonotum without parapsidal furrows.............

Io. Mandibles at apex 3-dentate.

Front wings with two cubital cells. (North

America.) ............. Neophotopsis, Ashm. (partim).

I I. Second cubital cell triangular; ocelli large; flagellum cylindrical, the first joint longer than wide, but shorter than the second. (North America.)...................... Micromutilla, Ashmead.

(Type Photopsis nana, Ashm.)

Second cubital cell small, irregularly pentagonal; ocelli not large, close together in a triangle. (South

America.) ................ Scaptodactyla, Burmeister.

(Type S. heterogama, Burm.)

I 2. Mandibles strong, 3-dentate at apex.

Front wings with only one recurrent nervure; first abdominal segment smooth, or at most only sparsely feebly punctate ............. Neophotopsis, Ashm. (partim).

Front wings with two recurrent nervures; first abdominal segment distincțly, closely punctate........ Photopsis, Blake (partim). 
13. Ocelli large; submedian cell not or rarely much longer than the median; first abdominal segment closely punctate. (North America.) ........................ Photopsis, Blake.

(Type P. imperialis, Blake.)

Ocelli small ; submedian cell longer than the median; first abdominal segment smooth, impunctate. (North

America.).................... Nomiæphagus, Ashmead.

(Type Mutilla Sanbornii, Blake.)

14. Oceili large; submedian cell a little longer than the median; two recurrent nervures, the second, however, sometimes incomplete or subobsolete at apex; first joint of the flagellum about twice as long as thick. (North America.).......... Pyrrhomutilla, Ashmead.

(Type Sphærophthalma anthophoræ, Ashm.)

15. Mesonotum without parapsidal furrows ................ Mesonotum with parapsidal furrows .................. 8 .

I6. Thorax about twice as long as wide, not wider than the head.... i 7 . Thorax not mush longer than wide, wider than the head.

Submedian cell not longer than the median ; flagellum cylindrical, tapering off at apex, the fourth joint not much longer than the second ; second ventral segment more or less conically produced or elevated at basal middle. (Australia.). Eurymutilla, Ashmead.

(Type Mutilla affinis, Westw.)

I7. Submedian cell longer than the median; flagellum cylindrical, the first joint shorter than the second; second ventral segment normal. (Australia.) ................... Ephutomorpha, André. (Type Mutilla aurata, Fabr.)

I8. Front wings with two cubital cells.................. Front wings with three cubital cells.

Head subglobose; ocelli small. Australia. Bothriomutilla,Ashmead.

(Type Mutilla rugicollis, Westw.)

I9 Head subquadrate; ocelli small ; mandibles excised beneath, 2. or 3-dentate (teste André.) (South America.) ...... Tallium André.

(Type Mutilla tenebrosa, Gerst.)

20. Thorax not or hardly twice as long as wide, usually narrowed posteriorly, but never very elongate ............... Thorax elongate, thrice as long as wide, or nearly, obpyriform....29.

2I. Thorax at least $\mathrm{I} 1 / 2$ times as long as wide, obtrapezoidal, obovoid, obpyriform, or banjo shaped, or nearly $\ldots \ldots \ldots \ldots \ldots \ldots 24$. 
Thorax not or only a little longer than wide, quadrate or nearly, obtrapezoidal, short ovoid or otherwise shaped.

Thorax obtrapezoidal or short ovoid.............

Thorax hexagonal, a little wider than long, punctate; head subglobose; first and second joints of the flagellum only a little longer than thick. (Australia).. Eurymutilla, Ashmead.

(Type Mutilla affinis, Westw.)

22. Thorax at least $\mathrm{I} 1 / 2$ times as long as wide $\ldots \ldots \ldots \ldots \ldots \ldots \ldots \ldots$.

Thorax obtrapezoidal and only a little longer than wide.

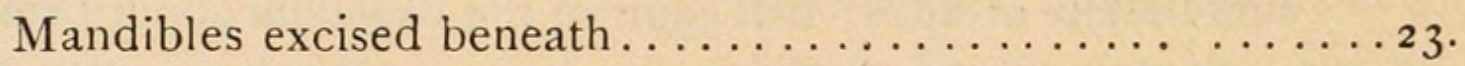

Mandibles not excised beneath.

Mandibles conically pointed edentate; first and second joints of the flagellum small, not longer than wide, the third joint longer than the second .. Micromutilla, Ashmead. Mandibles falcate, but with a small tooth within before the apex; first joint of the flagellum much longer than wide and longer than the second... Neophotopsis, Ashmead.

23. Mandibles decussate, acute at apex, but with a minute tooth within before the apex........... Odontophotopsis, Viereck.

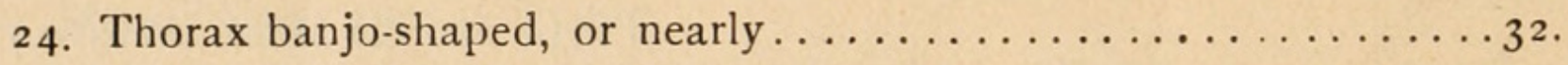
Thorax obovoid or obpyriform.

Head transverse quadrate, the temples broad; eyes oval or ellipsoidal ; highly polished.

Mandibles long, acuminate decussate, edentate, first joint of the flagellum long, obconical, longer than the 2 nd and 3 rd united....? Neophotopsis, Ashm.

Thorax obtrapezoidal.

Head subglobose, the temples rather broad; eyes ellipsoidal or nearly round.

Scape very long; first joint of flagellum very long; mandibles long, slender, pointed at apex, with two teeth within....... Scaptodactyla, Burmeister.

Scape normal ; first joint of flagellum not especially long.

Left mandible with an incision beneath toward base. 
Mandibles bidentate; first joint of the flagellum long, fully as long as 2 nd and 3 rd united .. ? Tetraphotopsis, Ashm. Mandibles acuminate, decussate, without teeth ; first joint of the flagellum obconical, longer than the second..?Neophotopsis, Ashm. Left mandibles without an incision beneath, simple..............? genus.

24. Thorax banjo-shaped, or nearly, much contracted at the sides $\cdots 33^{2}$. Thorax obpyriform, obovoid or obtrapezoidal. . . . . . . .

25. Mandibles beneath simple, not excised............... 26 . Mandibles beneath, or at least the left mandible, excised and usually with a process or projection before the incision........

26. Mandibles at apex 3 -dentate...................

Mandibles at apex simple or at most with a small tooth within before apex, or bidentate.

Head rather large quadrate or subquadrate, the temples broad................ Nomiæphagus, Ashmead.

27. Head subglobose, the temples not especially broad, the antennal foveæ not deep, without a carina superiorly... Brusia, Ashmead. 28. Pygidium smooth, without a pygidial area; eyes short, oval................. Tricholabiodes, Radoszkowski. Pygidium not smooth, with a pygidial area.

Body bare or nearly, at the most clothed with a sparse pubescence.

Mandibles edentate, pointed at apex; first joint of the flagellum not, or scarcely, longer than wide, and very little longer than the second. Photopsis, Blake.

Body clothed with a dense pubescence.

Mandibles acuminate, but with a slight tooth within before apex............... Pyrrhomutilla, Ashmead.

29. Thorax coarsely, rugosely punctate, pitted or foveolated, the front margin truncate, the angles acute or toothed, the lateral margins with a prominent tooth at the beginning of the contracted portion or in the tegular region..................

Thorax not coarsely, rugosely punctate or pitted, although punctate, the front angles rounded, the lateral margins without a tooth. 3 I. 
30. Head above bare; mandibles stout edentate, antennal foveæ bounded by a sharp carina superiorly ; first joint of the flagellum twice as long as the second............ Bothriomutilla, Ashmead. Head above clothed with a dense, white pubescence; mandibles elongate, pointed at apex; antennal foveæ not bounded by a carina superiorly; first joint of the flagellum only a little longer than the second (South

America).......... Leucospilomutilla, Ashm., gen. nov.

(Type Mutilla cerberus, Klug.)

3I. Head transverse or subglobose, bare or nearly; the eyes rounded, very prominent ; antennal foveæ bounded by a carina superiorly ; mandibles edentate; first joint of the flagellum much longer than the second (Australia)........... E.phutomorpha, André.

(Type Mutilla aurata, Fabr.)

32. Head large, subquadrate, somewhat wider than the thorax, but with the hind angles rounded and beneath normal, linarmed; mandibles long, bidentate (South America).... Tilluma, André.

(Type Mutilla spinosa, Swederus.)

Head very large, quadrate, wider than the thorax, the hind angles acute, and armed on each side beneath with a strong tooth; mandibles long, acute, with a tooth within much before the middle (South America)............... Atillum, André.

(Type Mutilla bucephala, Perty.)

\section{A NEW ANOPHELES WITH UNSPOTTED WINGS.}

EY D. W. COQuillett, Washington, D. C.

Anopheles Barberi, new species._-Near Walkeri, but only about half as large, the upright forked scales of the occiput chiefly yellowishwhite, body devoid of scales, etc. Black, the base of the antennæ, clypeus, stems of halteres, coxæ and trochanters yellow, thorax and scutellum yellowish-brown, front portion of the former and the pleura more yellowish, occiput devoid of appressed scales; thorax somewhat polished, thinly bluish-gray pruinose, the hairs and bristles chiefly black, those of the abdomen mostly yellowish, of the coxæ yellow ; femora with a distinct bluish tinge, tarsal claws simple; wings hyaline, the scales brown, the lateral ones lanceolate, petiole of first submarginal cell about one-third as long as that cell, base of the latter much nearer the base of the wing than that of the second posterior cell, hind crossvein less than its length from the small crossvein; length, $3 \mathrm{~mm}$.

Three females, collected August I 4 th, 1902, and August I 7 and 19 , I 903, on Plummer's Island, Maryland, by Mr. H. S. Barber, after whom the species is named. Type No. 6959, U. S. National Museum. 


\section{$2 \mathrm{BHL}$ Biodiversity Heritage Library}

Ashmead, William H. 1903. "CLASSIFICATION OF THE FOSSORIAL, PREDACEOUS AND PARASITIC WASPS, OR THE SUPERFAMILY VESPOIDEA." The Canadian entomologist 35, 303-310. https://doi.org/10.4039/ent35303-11.

View This Item Online: https://www.biodiversitylibrary.org/item/22193

DOI: https://doi.org/10.4039/ent35303-11

Permalink: https://www.biodiversitylibrary.org/partpdf/157312

\section{Holding Institution}

MBLWHOI Library

\section{Sponsored by}

MBLWHOI Library

\section{Copyright \& Reuse}

Copyright Status: NOT_IN_COPYRIGHT

This document was created from content at the Biodiversity Heritage Library, the world's largest open access digital library for biodiversity literature and archives. Visit BHL at https://www.biodiversitylibrary.org. 